UDC 811.111

DOI https://doi.org/10.32841/2409-1154.2019.42.2.20

\author{
Mykhaylenko V. V., \\ Doctor of Philology, \\ Professor oftheDepartment of Translation and Philology \\ King Danylo University
}

\title{
GRAMMATICALIZING “WELL” IN CONTEXTS
}

Summary. This paper is focused will be on the adverb well which underwent grammaticalization [Lehmann, 1985] in the text fragments from the British National Corpus and 100 fragments retrieved from the novel "Theatre" by W. Somerset Maugham.According to Hopper and Traugott grammaticalization and lexicalization are the two phenomena developing the language referring mostly to the steps whereby particular items become more grammatical through time. They add that reanalysis modifies underlying representations, whether semantic, syntactic, or morphological, and brings about rule change [Hopper 2003; see also Mykhaylenko, 2015]. There is a discussion whether grammaticalization and reanalysis are independent or designate the same change [Detges, 2002]. We shall consider grammaticalization as a feature of language evolution, a semantic change in particular, and reanalysis as a method of investigation on any synchronic plane. Traditionally it is designated as an open part of speech. However, the discourse analysis of well reveals its various functions - an adverbial modifier, a conjunction, a particle, an interjection, and a pause filler. Such an array of functions of well is proved by the British National Corpus analysis where its frequency is 141317 . Evidently, that its high frequency is caused by the processes in the class of adverbs revealed in different types of context. Most English parts of speech are demorphologized and their syntactic positions confirm their part of speech status [Hengeveld, 2010; Jezek, 2009]. We assume that the change primarily occurring in discourse and then permeating the system within the time is grammaticalization - an evolutionary process caused by syntactic reanalysis and semantic bleaching. In the following section we shall examine the text fragments with the unit well to define the shift of its open part of speech category to the close class of words: particles, interjections, conjunction, discourse marker, and pause filler.etc.Adverbs with the complex semantic structure can be transposed into particles, interjections, etc. (see Shigurov, 2016) which are used by the author/speaker to express his/her intentional meaning or for the discourse cohesion.

Key words: adverb, particle, discourse-marker, дискурсмаркер, intensifier, context, контекст, grammaticalization, reanalysis.

Introducion. In this paper we will concentrate on the polyfunctional unit well, which has been extensively investigated from synchronic and diachronic perspectives [see Watts 1989; Jucker 1993, 1997; Schourup 2001; Marcus 2009; Innes 2010 et al]. The School, Academic, and Universal grammars selected the three major principles of designating word classes, which have been preserved for many a century - semantic, formal, and functional. However, they are efficient enough for the prescriptive type of grammar where every language unit is assigned to adefinitecategory.
We understand that the language is in a constant flux and its units included, which can change their categorial status due to employing new positions and functions, expanding their meaning. [see 10, p. 1].

According to Hopper and Traugott grammaticalization and lexicalization are the two phenomena developing the language referring mostly to the steps whereby particular items become more grammatical through time. They add that reanalysis modifies underlying representations, whether semantic, syntactic, or morphological, and brings about rule change $[8$, p. 2; see also 16, p. 215]. There is a discussion whether grammaticalization and reanalysis are independent or designate the same change [6, p. 151]. We shall consider grammaticalization as a feature of language evolution, a semantic change in particular, and reanalysis as a method of investigation on any synchronic plane.

The focus of this paper will be on the adverb well which underwent grammaticalization [see 13, p. 305] in the text fragments from the British National Corpus and 100 text fragments retrieved from the novel "Theatre" by W. Somerset Maugham.

State of the art. There are two ways in researcheither we put forward a theory and then testit(hypothetical-deductive)t, or we generate a theorybased on the language data. We choose the latter (inductive approach) and, accordingly,we will try to segment the discourse into its constituents: paragraphs $\rightarrow$ sentences $\rightarrow$ parts of the sentence expressed by parts of speech [see 5, p. 1-2]. In our investigation the original adverb well is the object under study. Traditionally it is designated as an openpart of speech. However, the discourse analysis of well reveals its various functions - an adverbial modifier, a conjunction, a particle, an interjection, and a pause filler. Such an array of functions of well is proved by the British National Corpus analysis where its frequency is 141317 . Evidently, that its high frequency iscaused by the processesin theclass of adverbs revealed in different types of context. Most English parts of speech are demorphologized and their syntactic positions confirm their part of speech status [cf. 7, p. 530], in other words, 'actualize their part of speech designation [10, p. 402-403].

A more specific definition of grammaticalization is provided by Roberts and Roussou who regard it as "a categorial re-analysis, creating new functional material" [18, p. 2]. In terms of approaches to grammaticalization, there are many perspectives from which the phenomenon of grammaticalization can be related to a broader linguistic framework. [14, p. 69-70]. There is another term the transcategorization, which means the categorial shift of a lexical item with no superficial marking, resulting from its employment in a new (morpho) syntactic environment [10, p. 392].

We assume tha the change primarily occurring in discourse and then permeating the system within the time is grammaticalization - an evolutionary process caused by syntactic reanalysis and semantic bleaching. In the following section we shall examine the text fragments with the unit well to define the shift of its 
open part of speech category to the close class of words: particles, interjections, conjunction, discourse marker, and pause filler.etc. Adverbs with the complex semantic structure can be transposed into parenthetic-modal words or particles [see20, p.136] which are used by the author/speaker as discourse cohesion unit.

Corpus analysis. Section 1.0. Well etymology.First, we shall start with the etymology ofwell (adv.) to explore its meaning dynamics: Old English "wel, expresses" in a satisfactory manner, "abundantly, very, very much; indeed, to be sure; with good reason; nearly, for the most part". It came from from the Proto-Germanic *wel- (source also of Old Saxon wela, Old Norse vel, Old Frisian wel, Dutch wel, Old High German wela, German wohl, Gothic waila "well"), and in its turn it developed from from the Proto-Indo-European root *wel "to wish, will" (source also of Sanskrit prativaram "at will", Old Church Slavonic vole "well", Welsh gwell "better", Latin velle "to wish, will", Old English will an "to wish"; see will (v.)). It was also used in Old English as an interjection and an expression of surprise.

Section 2.0. The definitional analysis of well

The definitional analysis of the four dictionary entries has revealed three main groups of components of well: (1) justly, rightly; fully, clearly, elegantly, advantageously, satisfactorily, sensibly, considerably, attentively, readily; (2) indeed; (3) wish. The fist components (see 1-3) constitute the original adverbial meaning or their own identity [see Komarik]; the second group (see 4-5) expesses the speaker's mode: a qualitative intensifier; an emotional attitude, and a wish. And the last component refers to thediscourse cohesion means such as: (6) discourse introduction)[Merriam Webster,Cambridge]; (7) a marker of topic change [Collins], (8)a frame marker [MacMillan].

Section 3.0. Classification of well functions in the literature

Jucker specifies that the discourse marker well has four distinct uses in Modern English: as a frame it introduces a new topic or prefaces direct reported speech; as a qualifier it prefaces a reply which is only a partial answer to a question; as a face-threat mitigator it prefaces a disagreement; and as a pause filler it bridges interactional silence [11, p. 91]. In each group the part of speech meaning is actualized: (1) adverb, (2) particle, and (3) discourse marker. From the perspective of the parts of speech theory the two groupsof well can be singled out to be correct. We must stress that the adverb feature and the interjection feature have come from the Old English Period, while the discourse marker feature, particle, conjunction, orpreposition has developed in Modern English

Svartvik proposes four classes of wellfunctions: (1) a frame-marker, or a topic shifter,and a direct speech introductory [21, p. 167-168], e.g.

(i) Has anyone, I mean has anyone had that experience? Yes?

Well I got a video (pause) and, like, that's allwe got. (ii) But what the hell is she doin' here?" Well, you'd better ask her." (iii) Well,' said Melanie.' I am so sorry!

In the given fragment well functions on the text level as a textstructuring device. It can be also called as a discourse organizer to reveal "relationships between prior and coming discourse" $[2$, p. 384)]. However, in the framework of the parts of speech theory it isaconstituent of the particle paradigm. Discourse markers - words like so, and, or $y$ 'know- may have both grammatical and discourse meanings, and they are multifunctional. Most linguists would agree that discourse markers contribute to the cohesion of the discourse by signaling or marking a relationship across utterances [23, p. 65]. Any particular discourse marker can function differently in different contexts of use. Meanings of discourse markers can vary both by communicative context and by discourse context.
(2) Owen says that well can be used as a face-threat mitigator, indicating some problems on the interpersonal level. Either the faceof the speakeror thefaceof thehearer is threatened. [17, p. 99-100], e.g.:

(i) "Both of you! We've more to worry about". "Well, just keep an eye on it," said Duvall. (ii) The member stiffened, then edged away in a fading mumble: Well, I suppose things must be rather trying foryou, what with...

(iii) Well can be used as a qualifier, indicating some problem on the content level of current or preceding utterance [21], e.g.:

(3.1) Well, is there a time when Big Tree stops being a plant a bit dubious what they do with the profits after. (3.2) I must admit I'm very hungry. Well so you should be. (3.3) 'Still, yer got nice looks,' said Ella.' Well, thanks,' said Dolly.

(4) Well can be used as a pause filler to bridgeinteractional silence. It also indicates some problems on the interpersonal level between the speaker and the hearer, e.g.: (i) Well no, I mean, a - (pause) tha - even that - that one the otherday. (ii) Oh well it's, it's where (pause) they say (pause) say a sequence of underground. (iii) yeah well, well it's like a spongy now.

Section 4.0. Classification of well in the corpus.

In the following section we shall proposea positional classification of well [see 4]. The syntagmatic change of the original distribution of well bound to the verb brought the semantic loss of well.

(a) The initial position of wellin the British National Corpus has frequency $-40(100)$, and in the novel - 37(100), e.g.:

(i) Well, is there a time when Big Tree stops being a plant. (ii)Well it's (pause) blue. Mm. (iii) Well, what is it?

These illustrations (i-iii) prove the semantic loss of well in the sentence initial position and it can function as a topic shifter and the following functions can distinguish in thecontext: response markers,negative response markers, evaluative response marker, attention markers, attention markers, disagreement, floor shifters [3; 1].

(b) The midposition, between utterances well in the British National Corpus has frequency - 11 (100), in the novel it is 28, e.g.: (i) yes, the, yeah well, well it's like a spongy now. (ii) That's also in six, oh well then so the twoboys raced down the harbor. (iii)The first thing I should do is say well what are the key tasks, what are theareas that would mean results?

These illustrations (i-iii) reveal the function of well that of a pause-filler with the semantic loss.

(c) The sentence final position of well (or bound to the verb in its pre-and post-position) in the British National Corpus has frequency -20 (100), in the novel it is - 19(100), e.g.:

(i) Oh aye, yes [I] know them very well. (ii) In the right type of country projected profiles may illustrate the relief remarkably well. (iii) if it is not successful, build on the things that go well?

These samples attest to retaining the original meaning of 'manner' by the adverb well. To this group we can refer the combination of as +well

(d) The combination of 'as + well' points to 'sameness' of an event or an activity in the British National Corpus has frequency - 4 (100), in the novel it is 16(100), e.g.:

(i) Well my feet ache as well, my legs as well. (ii) You are also advised to avoid that areaas well. (iii) there, hammer some more tenterhooks in somewhere else and put it on there as well.

The combination of 'as + well + as' is used in the function of conjunction (since15th century) and preposition (since 1589) in the sentence structure, and has its frequency in the British National Corpus - 12 (100) and in the novel - 16(100), e.g.: 
(i) I do my job as well as I can, so please respect me. (ii) The cloud cover as well as the atmospheric conditions are precisely defined. (iii) It became clear that the scandal involved opposition party members as well as members of the LDP.

In my opinion, the syntagmatic change of well is secondary, whereas the speaker's intention is the primary cause.

Conclusion. The phenomenon of grammaticalization is not new but it attracts the scholars due itspossibility to explain thechanges in the language. Every nowand then researchers try to overhaul the parts of speech system or at least to renovate it specifying contextual functions of some parts of speech, primarily, of the close or functional ones and defining them as a separate part of speech. The adverb is the best example for such manipulation as it used to be called as "a waste-paper basket" in English linguistics.

The data presented in this paper demonstrate that adverb well in an irregular distribution can lose or bleach its dominant semantic componentand reveal its new or, perhaps,periphery components, like those of particle, interjection, conjunction, preposition, discourse marker, pause filler. Such polyfunctionality of the adverb supports its flexibility and sustainability of the parts of speech system so far.

\section{References:}

1. Aijmer Karin. English discourse particles: Evidence from a corpus. Studies in corpus linguistics. Amsterdam and Philadelphia : John Benjamins, 2002. xvi, 299 p.

2. Biber Douglas E, Conrad Susan, Corte Viviana. If you look at ... Lexical bundles in university teaching and textbooks. Applied Linguistics. 2004. Vol. 35. № 3. P. 371-405.

3. Brinton L. The development of discourse markers in English / ed. J. Fisiak. Historical linguistics and philology. Berlin: Mouton de Gruyter, 1990. P. 45-71.

4. Carlson Lauri. 'Well' in dialogue games: A discourse analysis of the interjection 'well' in idealized conversation. Amsterdam and Philadelphia : John Benjamins, 1984. $113 \mathrm{p}$.

5. Degand Liesbeth Simon, Anne Catherine. On identifying basic discourse units in speech: theoretical and empirical issues. Discours. 2009. Vol. 4. P. $1-55$.

6. Detges Ulrich, Waltereit Richard. Grammaticalization vs. Reanalysis: a semantic pragmatic account of functional change in grammar. Zeitschriftfür Sprachwissenschaft. 2002. Vol. 21. № 2. P. 151195.

7. HengeveldKees, Lier Eva van. An implicational map of parts of speech.Linguistic discovery. 2010. Vol. 8 (1). P. 129-156.

8. Hopper P., Traugott E.C. Grammaticalization. Cambridge : CUP, 2003. $300 \mathrm{p}$.

9. Innes B. Well, that's why I asked the question sir: Well as a discourse marker in court. Language in Society. 2010. Vol. 39. P. 95-117.

10. Ježek Elisabetta, Ramat Paolo. On parts-of-speech transcategorization. Folia Linguistica. 2009. Vol. 43. Issue 2. P. 391-416.

11. Jucker Andreas H. The discourse marker well in the history of English. English Language Linguistik. 1997. Vol. 1. P. 91-110.

12. Komarik Miroslav. Autosemantic parts of speech in Czech /Ed. Eva Hajicova et al.Prague Linguistic circle papers (Travaux Du CercleLinguistique de Prague).Vol. 3. Amsterdam/Philadelphia : John Benjamins Publishing, 1999. P. 195-210.

13. Lehmann Christian. Grammaticalization: Synchronic variation and diachronic change. Lingua e Stile. 1985. Vol. 20. P. 303-318.

14. Machová Dagmar. Polyfunctionality and the ongoing history of English modals.Ph.D. diss. Olomouc : Palacký University inOlomouc, 2015. 197p.

15. Marcus Nicole E. Continuous semantic development of the discourse marker well. Journal of English Studies. 2009. Vol. 9. Issue 2. P. 214-242.
16. Mykhaylenko V.V. Modal adverb transposition in Old English. Studia Philologica. 2015. Issue 5. P. 215-239.

17. Owen Marion. Conversational units and the use of 'well. / ed. P. Werth. Conversation and Discourse. London : Croom Helm, 1981. P. 99-116.

18. Roberts Ian, Roussou Anna. Syntactic change: A Minimalist approach to grammaticalization. Cambridge : CUP, 2003. 288p.

19. Schourup L.C. Rethinking 'well.' Journal of Pragmatics. 2001. Vol. 33. P. $1025-1060$.

20. Shigurov V.V. Semantic foundations of transposition of language units from adverbs into parenthetic-modal words and expressions. European Journal of Natural History. 2016. № 4. P. 136-139.

21. Svartvik Jan. Well in conversation. / ed. Sidney Greenbaum et al. English linguistics for Randolph Quirk. London : Longman, 1980. P. 167-177.

22. Tanne Deborah et al. (eds.). The Handbook of discourse analysis. Malden, MA : Blackwell, 2015. 952p.

23. Torres L. Bilingual discourse markers in Puerto Rican Spanish. Language in Society. 2002. Vol. 31 (1). P. 65-83.

24. Watts Richard J. Taking the pitcher to the 'well': Native speakers' perception of their use of discourse markers in conversation. Journal of Pragmatics. 1987. Vol. 13. P. 203-37.

\section{Михайленко В. Граматикалізація WELL у контекстах}

Анотація. Стаття присвячена прислівнику well, який зазнав трансформації граматикалізації в англійській мові (Lehmann, 1985). Дослідження базується на текстових фрагментах із Британського національного корпусу та 100 фрагментах, дібраних iз роману «Театр» У. Сомерсета Моема. На думку Хоппера та Траугот, граматикалізація та лексикалізація - це два явища, що змінюють мову, особливо це стосується окремих частин мови типу прислівника. Відбувається еволюційний перехід лексеми у грамему - зміна правил синтагматики та семантики [Hopper 2003; див. також Mykhaylenko, 2015]. Точиться дискусія навколо понять граматизації та реаналізу як незалежних явищ або синонімічних [Detges, 2002]. Ми розглядаємо граматизацію як особливість еволюції мови, зокрема семантичну зміну, а реаналіз - як метод дослідження в будь-якій синхронічній площині. Традиційно прислівник належить до «відкритих» частин мови. Однак дискурс-аналіз виявляс функції, що несумісні з його семантикою та синтагматикою - сполучника, частки, прийменника, когезійного маркера дискурсу, вигуку та заповнювача пауз. Такий набір функцій підтверджується аналізом текстових фрагментів Британського національного корпусу, де його частота становить 141317 . Вочевидь, його висока частотність зумовлена процесами, які відбуваються у самому класі прислівників - перегрупуванням домінантних і периферійних компонентів значення, але вони проявляються тільки у певних типах контексту. Більшість англійських частин мови «деморфологізовані», а їхня синтаксична позиція вказує на їхній частиномовний статус [пор. Hengeveld, 2010; Jezek, 2009]. Ми припускаємо, що зміна, яка відбувається насамперед у дискурсі, а потім пронизує всю мовну систему, - це граматикалізація, еволюційний процес, спричинений зміною синтаксичної позиції та семантичною втратою. Ми розглянули текстові фрагменти з одиницею well для визначення іiі транспозиції: «відкрита» частина мови $\rightarrow$ «закрита» частина мови (частка, вигук, сполучник, прийменник, еtc). Відповідно, прислівники зі складною семантичною структурою можуть трансформуватися у частки, вигуки, сполучники тощо [див. Шигуров, 2016] у певних контекстах, які автор використовує для вираження своєї інтенції або для когезії дискурсу.

Ключові слова: прислівник, частка, дискурс-маркер, інтенсифікатор, контекст, граматикалізація. 